\title{
A VISION OF A CYBORG EDUCATION ${ }^{1}$
}

Daniel S. Friedrich ${ }^{(*)}$

The Vision (King et al.) opens up with a white suburban couple bickering as they bring a plate with warm cookies to their new neighbors. The husband doesn't see the point in offering cookies to robots, which probably don't need to eat. To which the wife responds: "They are not robots. I went online. They are something else. They are synthe-somethings". "Honey, I love you, but they are toasters. Fancy, red toasters. They are not like you and me. They don't eat cookies, y'know?," he replies as Vision opens the door. Right after Vision and his wife, Virginia, thank the human couple for the cookies and offer to set up a dinner one night, they dump the cookies in the garbage can and converse on what they see as a meaningless act. That is when Vision lectures his wife Virginia: "To assert as truth that which has no meaning is the core mission of humanity."

The Vision ${ }^{2}$ is a 12 -issue comics series published in 2015-2016 by Marvel, written by Tom King and illustrated by Gabriel Hernandez Walta and Michael Walsh, focusing on Vision, a "synthezoid" Avenger. In this series, Vision decides to attempt to join the human experience by literally creating a family for himself (wife Virginia, daughter Viv, and son Vin) and moving to a suburban home in Arlington, Va. While Vision "works" as a superhero, Virginia is a stay-at-home mom, and both kids go to school. But the Visions do not try to hide their inhumanity: their faces are bright red and metallic, they have no pupils in their eyes, and they openly use their powers. Their mailbox seems to be the only one on the typical white suburban block to hover using tiny rockets, instead of merely standing on a pole. Countering a more traditional superhero trope, there are no secret identities here. Thus, The Vision centers its attention on a very specific pedagogic act: the failed attempt at learning to be human by beings stuck in the middle of a human/non-human existence. ${ }^{3}$

In this essay, I will delve into the broad question of whether to be human can be learned, and what the implications of this question are for thinking of the othering processes that we subject those who we deem as never-fully-human to. What, specifically, is being learned by those who endeavor to learn to be human, yet are constantly cast into the unlivable spaces of sub-humanity? And how would those learning processes be different if we attempted a de-centering of the human from

\footnotetext{
${ }^{1}$ I would like to thank Elizabeth and Jordan for their feedback and stimulating conversations, which have deeply informed this essay.

${ }^{(*)} \mathrm{PhD}$ Chair, Dept. of Curriculum \& Teaching. Associate Professor of Curriculum.Teachers College, Columbia University.308B Zankel.

2 I will use "The Vision" to discuss the series, "Vision" for the character, and "the Visions" for the family.

${ }^{3}$ In order to discuss the series, this essay will have spoilers galore.
} 
pedagogical thinking? The Vision will serve as a catalyst for considering what a post-humanist pedagogical thought might entail, at a time in which the very humanity of vast sectors of the population is being questioned and undermined. Drawing inspiration from the work of contemporary post-humanist thinkers, such as Donna Haraway and Rosi Braidotti, and complementing it with the political philosophy of Jacques Rancière, the piece aims not at merely producing "more inclusion", but at shifting the gaze by decentering the human at the core of traditional conversations on inclusion/exclusion.

\section{THEY MIGHT HAVE BRIGHT RED FACES, YET...}

One of the most striking issues regarding this outstanding comic series is the way in which race and racialization can be read into it, without the topic being overtly addressed. As the Visions attempt to experience humanity, it becomes almost immediately clear that what they are trying to incorporate themselves into is white middle-class America. The suburb they live in, the school the kids attend, and the kinds of interactions they tend to read as "typically human," ooze whiteness. The fact that Vision assumes that this is the kind of place where humanness is to be found, or where the average person experiences what it means to be human, speaks to the power of whiteness stemming from its construction as the unspoken norm (see e.g. Leonardo; Leonardo and Broderick)

Yet whiteness is not only a location, but also a way of acting in the world. Let's take, for example, the following scene. After a classmate tries to bully Vin, he holds him by his throat and makes it clear that it would be easy for him to kill the bully. This leads to the principal calling Vin's parents into his office to let them know that Vin will be expelled. During that conversation, the principal calls Vin and Viv, "things", "guns", or "metal in a shape that can kill," clearly concerned about the safety of the rest of the students. Vision stands up, and tells the principal that his son will not be expelled, but will be suspended like any other kid would. When the principal reacts by claiming that Vision cannot decide that, the synthezoid responds: "I am The Vision of the Avengers. I have saved this planet 37 times. Each day you live, each breath you take, each beat of your heart. Each is due to my actions. 37 times over. You are quite correct, it is not my decision to make. It is merely my considered opinion that this is the proper course of action. But I do believe that you will recognize that fighting me in this matter will not in the end prove to be beneficial." Is there anything more white than this sense of entitlement?

The superhero-savior expects to be owed a debt of gratitude by those who did not participate in the conversation about their own role in the act of saving. It is ironic that this conversation is taking place within a school, given the long history of salvationist discourses within education (see 
e.g. Popkewitz).The scene points to the intimate relation between the narratives of the (usually white) teacher as savior of (mostly black and brown) children - quite dominant within pop culture ; school's own role in colonial projects of civilizing the seemingly barbarian (Pineau) through an education seen as a tool for bringing the sub-human closer to the normative model of the white European man; and the neoliberal idea of reform to be pushed by parents advocating for their individual children's rights that undermines the notion of schooling as a public good. When Vision advices the principal not to expel Vin, he is merely embodying a patriarchal white supremacy in a place built and suffused of the principles that make that system possible and part of the foundations of American society.

However, there is a counter current flowing through. Early on in the series, it becomes evident that no matter what they do, regardless of whether they follow all the rules, of whether they manage to keep their powers in check, or whether they learn to take on all the bullying without responding to it in ways that would certainly end it, the Visions will never be considered (fully) human, or even lives worth living. Throughout the series, they are usually referred to by people surrounding them as "things," and during the first scene in which Vin arrives at his new school, a female student looks at him, and shows him a computer screen that reads: "R U NORMAL?"

There is also a scene that is repeated, to different effects, twice in the series. The first time is a flashback, with Vision lying naked in bed with his then wife Scarlet Witch (a human), and Vision telling her a joke: "Two toasters are sitting on a counter. One toaster turns to the other toaster and asks: 'Do you sometimes feel empty?' Then the other toaster says: 'Oh my God, a talking toaster!"'. This causes Scarlet Witch to burst into laughter. The scene is repeated several years later, with Vision telling the same joke in bed to Virginia (who was built and imprinted with Scarlet Witch's brain patterns, because comics), except that this time, there is no reaction on her part.

First Lesson. Returning to the guiding question for this essay - what specifically is being learned by those endeavoring to learn to be human? - perhaps the first thing they learn is they are not, and will never be, human. The Visions are continuously out of synch with their surroundings, and the things they are told make humans human, seem instead to re-inscribe the distance between human and machine: humor, reason, customs, faith, sex. The synthetic family's physical power, the patriarch's part as one of "Earth's Mightiest Heroes" and his role in saving the planet 37 times over, their home in suburban Virginia, are all tenuous, contingent aspects that allow them to feel, every now and then, like their project of learning to be human is achievable. Yet that contingency reveals itself at every step, when the gap between them and the people they seek acceptance from seems impossible to breach. 
This is not unlike historical and current conversations about the impossibilities of historically minoritized communities in the US to be considered fully human by a society founded on white patriarchal supremacy. As Black parents continue to talk to their kids about the scenes they witness on the media and in their lives about police brutality against their communities, attempting in many cases to reinforce the pragmatic need to follow certain behaviors that might minimize life-threatening risk, they also know that no behavior can guarantee their inclusion on the category of life-worth-protecting, or life-equal-to-mine, by the dominant majority.

During the comics run, the Visions respond to this realization in two different, yet complimentary ways. In the first half, with faith, described by Vin as "the highest form of cognition". During the first six issues of the series, the Visions are constantly causing harm to people around them, although always by accident or a miscalculation of their own power. A villain that breaks into their home is killed by Virginia in a protective fit of rage, a boy dies after his father tries to shoot at Virginia and she phases letting the bullet fly past her, and the family pet dog gets electrocuted when it digs out the poorly buried villain from the backyard. These incidents cause tension within the family, with the females bearing most of it, and Vision trying to hold it together. He has, after all, been accepted into the most trusted superhero group and it should be only a matter of time until the other members of his family get accepted as well. The family's faith is reflected in the fact that the children keep attending school and the father remains a superhero, defending the planet from threats big and small. But most importantly, the family acts as if, after each one of the incidents that should perhaps demonstrate their other-ness, they kept trying, everything would turn for the best. Vision lies to the police to protect his wife after the human boy is shot, and he uses the dead dog's brain to build a synthetic pet for the family. He is constantly struggling to get things back to where they should be, so that normal life might begin. Vision reassures his family that everything will be alright, if only they can get past this or that particular incident. This faith in a future that will be stabilized by a normality that was never actually experienced is what served as the foundational sentiment for the whole series. It is also a faith that is not necessarily shared with Virginia, who tends to question the enterprise and has a harder time merely following the rules and customs of what Vision understands as "humanity." However, even when her faith in the project falters, her faith in her partner does not.

Towards the end of the series, however, Vin is killed by accident by a spy (another synthetic being created by Vision's "father", considered thus by Vision his brother) sent to live with the Visions by the Avengers, who are suspicious of Vision's mental stability. To protect the spy from Vision's ire, the Avengers hold him in a special prison and hold the Visions in house arrest. It is at 
this point that all faith is gone, and Vision seems to turn into the menace the Avengers had feared he would become. The synthezoid gives up on the hope of being recognized as potentially human and ally, and fully embraces his non-human nature, seeking revenge for his lost son, in quite the "human" show of emotion. Vision defeats the Avengers, and right as he is about to strike the spy, Virginia shows up and kills him for her husband, taking the burden off of his shoulders and triggering her own suicide a few pages later.

One of the most powerful potentials of good sci-fi is that it presents us with allegories of the world or worlds that surround us, moving us to consider the what if's and the distance (or absence thereof) between those fantastic worlds and ours. The swing between hope and disbelief, between sticking to rules they know were not made for them, and breaking all conventions; the role of women in carrying on much of the burden after their children are killed, only to suffer the most dire consequences; and the heroic narratives that emerge from resilience and grit that paint survivors as superheroes only to provide cover for the system that was put in place for them to fail, are all too familiar themes in The Vision, regardless of capes, sentient circuits, and laser beams coming out of foreheads.

Second lesson. A second, complementary lesson is that beings considered fully human will never understand/become not-fully-human, at least not voluntarily. Marvel Comics is known to be the publisher that made superhero comics "hip" again in the 1960s, by shifting the paradigm of what superheroes could be, from idealized versions of ourselves (think of Superman or Wonder Woman), to flawed, complex characters that dealt with similar problems as we did, but in a different setting (Morrison). Yet while the teenage Peter Parker is bullied and never has enough money, and the mutant X-Men are discriminated against and never fully trusted, they still choose to put on Spandex and save the world. This is not the story of the Visions. Vision's main job is still to be an Avenger and save the world, yes, but we see little of that in this series, which focuses squarely on the family's attempts at what they read as a normal life. Even the few scenes that showcase Vision fighting a supervillain with the Avengers are used to communicate the tensions between this role and his part as a family man. But, as I mentioned before when narrating some scenes from the comic, the Visions are never regarded as more than things, things that believe to be alive, but things nevertheless.

The judges of what counts as human or alive are those who already belong to the category at stake, and since the boundary between human/non-human seems in the comic to be quite rigid, empathy does not seem like a possibility. The joke about the toasters and its repetition highlights this fact in a unique way: Scarlet Witch laughs because the idea of talking toasters seems ridiculous 
to her, despite being in bed with Vision. The synthezoid is, after all, shaped like a man and built to speak, though never as a fully-human being (which is why, we learn, they end up divorcing). Virginia does not laugh at all, because the distance between a talking toaster and herself is much smaller than that between herself and Vision's ex-wife. The question, for her, does not seem to be "why would a toaster speak?", but rather "why wouldn't it?"

The characters in the series never fully commit to the potentials of being-cyborg. In her famous theorizations of cyborgs, Haraway defines them as "a hybrid of machine and organism, a creature of social reality as well as a creature of fiction" (p.149) She continues:

The cyborg is resolutely committed to partiality, irony, intimacy, and perversity. It is oppositional, utopian, and completely without innocence. No longer structured by the polarity of public and private, the cyborg defines a technological polis based partly on a revolution of social relations in the oikos, the household. Nature and culture are reworked; the one can no longer be the resource for appropriation or incorporation by the other. The relationships for forming wholes from parts, including those of polarity and hierarchical domination, are at issue in the cyborg world. Unlike the hopes of Frankenstein's monster, the cyborg does not expect its father to save it through a restoration of the garden; that is, through the fabrication of a heterosexual mate, through its completion in a finished whole, a city and cosmos. The cyborg does not dream of community on the model of the organic family, this time without the oedipal project. The cyborg would not recognize the Garden of Eden; it is not made of mud and cannot dream of returning to dust. (p. 151)

The Visions would seemingly fall more clearly into Haraway's description of Frankenstein's monster, with the hope of salvation (their faith, as explored above) placed in imitating their creators ${ }^{4}$ lifestyle, in all its white, patriarchal, heteronormative might, rather than on the more subversive cyborg. Their efforts at following rules and maintaining the stereotypical model of "family life" is unfazed by the humans' lack of understanding and/or willingness to understand and trust them. In the process of learning the lesson taught by the gatekeepers to humanity, they keep knocking on that door, brushing under the rug all their difference.

Everyone except for Virginia. The "stay-at-home- mom" is perhaps the one cyborg in a family of Frankenstein's monsters. One more return to Haraway can be illuminating:

The main trouble with cyborgs, of course, is that they are the illegitimate offspring of militarism and patriarchal capitalism, not to mention state socialism. But illegitimate

\footnotetext{
${ }^{4}$ Technically, the Vision's creator's creator is human. Henry Pym created the robot Ultron, who then created Vision.
} 
offspring are often exceedingly unfaithful to their origins. Their fathers, after all, are inessential. (1991, p. 151).

Virginia seems to be the only one not seeking approval, and not caring about the fact that humans are not letting them in. Her use of her powers to kill the villain that had broken into her home and the spy that had been sent by the Avengers (going against one of the lynchpins of mainstream superhero comics: superheroes do not kill), her threatening stance over anyone attacking her family, her use of her own sexuality for pleasure and control, and finally, her crossing of the ultimate taboo by taking her own life, all make it harder to know whether she has learned (or been willing to learn) anything that would follow Vision's foundational mission.

Third lesson. Connected to this tension between the attitudes performed by Vision and the children, and Virginia, a third lesson that is learned by these non-humans in their experiment is that it is only through a return to that which makes them not-fully-human that something akin to salvation is to be found. One of the defining traits of the Visions is that they were not born, they were made. As such, one could theorize that they cannot die, a fundamental difference with their human counterparts. The series' last page, in fact, depicts Vision's effort to rebuild Virginia after she committed suicide, while singing (uttering?) "Row, row, row your boat/ gently down the stream/ merrily, merrily, merrily/ life is but a dream". Could this imply that Vision has given up on the attempt to learn what it means to be human, choosing instead to follow his wife's path? Once death is out of the equation, and life is just a dream, is learning still possible? At this point in the story, the Avengers have verified that their suspicions were well-founded: Vision could not be trusted. Neighbors and schoolmates were dead, and Vision seemed to be at a place of almost irredeemability. Most mainstream superhero comics, such as this one, would have focused on that "almost", finishing with a sacrifice that would reposition the main character as an undoubtable and incorruptible hero once again, for the next writer to use as they see fit. However, The Vision refutes that particular trope, deciding instead to embrace "the toaster", that is, the unheroic, non-human aspects of this specific character.

This third lesson opens up a series of questions: What would a post-humanist pedagogical thought look like, in light of The Vision? And why is this worth considering? The question about why is it worth considering can be answered in two different, yet complementary ways. On the one hand, many post-colonial scholars have argued that the Western construction of the human as a universal is in fact a quite particular gendered, raced, classed, able-bodied subjectivity that has been positioned as universal as a colonial, imperial foundational act (see e.g. Dabashi; Mignolo). Decentering that particular-universal could be seen, then, as part of a decolonial strategy. To this I 
would add a more Rancièrean perspective: that human is not a predetermined subject, but a political subject, that is, one open to dispute, to challenge in terms of who or what counts as human.

Political subjects are not definite collectivities. They are surplus names, names that set out a question or a dispute (litige) about who is included in their count. Correspondingly, freedom and equality are not predicates belonging to definite subjects. Political predicates are open predicates: they open up a dispute about what they exactly entail and whom they concern in which cases." (Rancière 303).

The protests by \#BlackLivesMatter activists, or by the Parkland youth are all part of that dispute or dissensus in terms of which lives are worth protecting and/or living, and who counts as fully human. The consideration of a post-humanist pedagogical thought, then, is part of the effort to allow for that dissensus to be part of the conversation about teaching and learning. A pedagogical thought that blurs the boundaries between human/non-human, that incorporates the assemblages of human and non-human actors as the unit of analysis and consideration, that examines how the toaster acts upon the hand that operates it, is a necessary aspect of social justice efforts to rethink and contest who is entitled to teach, learn, and experience curriculum.

\section{REFUSAL TO LEARN AND A CYBORG EDUCATION}

We live in a time obsessed with the maximization of learning and the uses of technology to optimize the intake and application of information. While teaching machines have a relatively long history (see e.g. Skinner), the reframing of the whole of education and schooling as an issue of learning is a newer phenomenon. Gert Biesta links the language of learning to:

a redescription of the process of education in terms of an economic transaction, that is, a transaction in which (1) the learner is the (potential) consumer, the one who has certain "needs", in which (2) the teacher, the educator, or the educational institution is seen as the provider, that is, the one who is there to meet the needs of the learner, and where (3) education itself becomes a commodity - a "thing" - to be provided or delivered by the teacher or educational institution and to be consumed by the learner. (p. 19, emphasis in the original).

Biesta states that one of the main issues with his turn is that "the only questions that can meaningfully be asked about education are technical questions, that is, questions about the efficiency and the effectiveness of the educational process" (p. 22, emphasis in the original). This displaces the political dimension of education, relegating it to the periphery of the conversation. Tests, accountability, rankings, and scripted curricula have all become part of the common sense of schooling, and the platform on which learning (content, to be a student, to be a citizen) stands as the 
reason and language of education. Students - especially those from minoritized groups - become "underperforming" or "at-risk" through these discursive practices, while schools appear to maintain a meritocratic faith that keeps telling them: "If you work hard enough and emulate your successful/white peers, you can make it as well. It's all on you."

But what if we took a page out of The Vision, and reimagined what a cyborg education might look like as a refusal to keep trying, a suspension of the faith in humanity or schooling as salvation? This is not about culturally relevant pedagogies (Ladson-Billings), or a different approach to teaching methods, as valuable as they are. This is also not about optimism versus pessimism. A suspension of the faith in schooling as salvation might force us to consider, on the one hand, those for whom schooling was never set up for yet are trapped within the confines of modern pedagogical-governmental thought, and on the other, the possibilities of a posthumanist educational thought. Just like cyborgs, modern schooling also has problematic parentage: colonialism, capitalism, and eugenics, to name a few. Yet schooling -as opposed to cyborgs- is by no means an illegitimate child. I would argue, however, that there is still space within schooling to be unfaithful to its origins.

If learning is centered around the human and his potential and future, a cyborg education decenters that human to focus instead on the assemblages of in/non/post-human actors and the egalitarian connections they enable, a "receptivity and global communication that deliberately blurs categorical distinctions (human/machine; nature/culture; male/female; oedipal/non-oedipal)" (Braidotti 200). This new focus requires a new language. I am particularly drawn to the work of Tyson Lewis (“A Case for Study”; On Study; “The Fundamental Ontology of Study”) who, drawing from Giorgio Agamben's political philosophy, reconceptualizes study as different from learning.

The studier prefers not to engage in self-actualization, dwelling perpetually in a state that is neither simply naïve ignorance nor mastery, constantly moving forward toward some kind of indeterminate goal while simultaneously withdrawing from the very idea of goals in the first place. While learning has a specific purpose with predefined success conditions, studying has, to borrow from Immanuel Kant, a kind of purposiveness without a purpose (an indefinite sense of rightfulness even if the goal seems to recede with every step forward).(Lewis, "The Fundamental Ontology of Study" 164).

Studying is, for Agamben, an "interminable" act, or an act without a determinate end. As a means without an end, studying is an open-ended quest with an indeterminate success condition... To study is to undergo a certain inoperativity where we are, to appropriate a phrase from Thomas Carl Wall's insightful study of Agamben, “exposed to all its [thought's] possibilities (all its 
predicates)" and yet are "undestined to any one or any set of them." (Lewis, "A Case for Study" 105)

A cyborg education could entail, thus, complementing this understanding of study as a refusal to enter into the logic of learning, with an attention away from the human subject and towards a different kind of assemblage. If Vision was - up to the death of his son- constantly trying to learn how to be human and imposing that desire on the rest of his family, Virginia was uncomfortably navigating a space that refused Vision's faith, dwelling in her toaster-ness. The synthezoids' immortality, the impossibility of them physically growing or maturing, their power to make their bodies either irrelevant (phasing) or over-relevant (increased density and strength), and their seemingly incapacity to fully understand humanity, would entail obstacles for learning to be human based on a rubric that could never be fulfilled. Yet for a cyborg education, they open up possibilities to different understandings of the purposes and processes of education. For instance, if there is no death, growth, or maturation, no one is ever behind or ahead, thus decentering the psyfield - and notions such as normal development or ability - from dictating the terms of a timely education (Friedrich). If bodies are both irrelevant and over-relevant depending on the needs and contingent situations of the students, then space, groupings, access, and interconnectedness could be rethought. And finally, if a pre-established notion of what it means to be human is destabilized and shifter away from a norm to emulate (yet for many, never fully reach) then the rhizomatic possibilities of difference may become the core of study.

The Vision is a fascinating comic series that invites us to explore the borders between humanity and inhumanity, to question how those borders get established, and what happens to those stuck in between. By theorizing the pedagogy inherent to that in-between space, this essay aimed at moving us away from a human-centered education, and towards a cyborg education that considers the possibilities that emerge when learning to be human is suspended, and the assemblage of non/in/post-human are allowed to become something otherwise.

Right before it is revealed that Vision is attempting to revive Virginia, a scene unfolds between Vision and his daughter Viv, the only "survivors" of the family, as Viv is leaving for school.

Vision: Did you pack a lunch?

Viv: Father, I do not eat. Why would I pack a lunch?

Vision: Perhaps the other children eat. And you wish to look normal. 
Viv: Two months ago, my uncle killed my brother. In response, my mother killed my uncle, then killed herself. And now I am a teenage synthezoid being raised by an Avenger.

Vision: I should have done better.

Viv: I am not normal, father. But I am late in getting started. And I must go. Goodbye Vision: Yes. Goodbye. 


\section{REFERENCES}

BIESTA, Gert. Beyond Learning: Democratic Education for a Human Future. Paradigm Publishers, 2006.

BRAIDOTTI, Rosi. "Posthuman, All Too Human: Towards a New Process Ontology.” Theory, Culture \& Society, vol. 23, n. 7-8, p. 197-208, 2006.

DABASHI, Hamid. Can Non-Europeans Think? Zed Books, 2015.

FRIEDRICH, Daniel. "We Brought It upon Ourselves": University-Based Teacher Education and the Emergence of Boot-Camp-Style Routes to Teacher Certification. Education Policy Analysis Archives, vol. 22, n. 2 , 2014. Disponivel em: <http://epaa.asu.edu/ojs/article/view/1193>.

HARAWAY, Donna J. Simians, Cyborgs, and Women: The Reinvention of Nature. Routledge, 1991.

KING, Tom, et al. The Vision. Marvel, 2018.

LADSON-BILlingS, G. But That's Just Good Teaching! The Case for Culturally Relevant Pedagogy. Theory into Practice, vol. 34, n. 3, p. 159-165, 1995.

LEONARDO, Zeus. The Color of Supremacy: Beyond the Discourse of "White Privilege." Educational Philosophy and Theory, vol. 36, n. 2, p. 137-152, 2004.

LEONARDO, Zeus; Alicia Broderick. Smartness as Property: A Critical Exploration of Intersections between Whiteness and Disability Studies. Teachers College Record, vol. 113, n. 10, p. 2206-2232, 2011.

LEWIS, Tyson E. A Case for Study: Agamben's Critique of Scheffler's Theory of Potentiality. Philosophy of Education Archive, 2012. p. 101-109.

. On Study: Giorgio Agamben and Educational Potentiality. Routledge, 2013.

The Fundamental Ontology of Study. Educational Theory, vol. 64, n. 2,pp. 163-178, 2014.

MIGNOLO, Walter D. Coloniality of Power and Subalternity. The Latin American Subaltern Studies Reader, edited by Ileana Rodriguez and María Milagros López, Duke University Press Books, 2001 . p. 224-44.

MORRISON, Grant. Supergods. Random House Digital, Inc., 2011.

PINEAU, Pablo. Education and Globalisation: A Latin American Perspective. History of Education, vol. 37, n. 6, p. 743-55, 2008. Taylor and Francis+NEJM, doi:10.1080/00467600802399504.

POPKEWITZ, Thomas S. Cosmopolitanism And The Age Of School Reform: Science, Education And Making Society By Making The Child. Routledge, 2008.

RANCIÈRE, Jacques. "Who Is the Subject of the Rights of Man?" South Atlantic Quarterly, vol. 103, no. 2/3, Spring 2004. p. 297-310.

SKINNER, Burrhus F. Why We Need Teaching Machines. Harvard Educational Review, vol. 31, p. 377-98, 1961. 


\section{ABSTRACT}

The Vision (King et al.) opens up with a white suburban couple bickering as they bring a plate with warm cookies to their new neighbors. The husband doesn't see the point in offering cookies to robots, which probably don't need to eat. To which the wife responds: "They are not robots. I went online. They are something else. They are synthe-somethings". "Honey, I love you, but they are toasters. Fancy, red toasters. They are not like you and me. They don't eat cookies, y'know?," he replies as Vision opens the door. Right after Vision and his wife, Virginia, thank the human couple for the cookies and offer to set up a dinner one night, they dump the cookies in the garbage can and converse on what they see as a meaningless act. That is when Vision lectures his wife Virginia: "To assert as truth that which has no meaning is the core mission of humanity."

Keywords: Cyborg Education. Curriculum. Interpretation of humanity.

\section{UNA VISIÓN DE UNA EDUCACIÓN DE CYBORG}

\section{RESUMEN}

The Vision (King et al.) abre con una pareja suburbana blanca discutiendo mientras llevan un plato con galletas calientes a sus nuevos vecinos. El esposo no ve el punto de ofrecer galletas a los robots, que probablemente no necesitan comer. A lo que la esposa responde: "No son robots. Me conecté. Ellos son otra cosa. Son sintaísimos". "Cariño, te quiero, pero son tostadoras. De lujo, tostadoras rojas. Ellos no son como tú y yo. Ellos no comen galletas, ¿sabes? ", Responde mientras Vision abre la puerta. Inmediatamente después de que Vision y su esposa, Virginia, agradecieran a la pareja humana por las galletas y se ofrecieran a preparar una cena una noche, tiraron las galletas en el bote de basura y conversaron sobre lo que consideran un acto sin sentido. Ahí es cuando Vision enseña a su esposa Virginia: "Afirmar como verdad lo que no tiene sentido es la misión central de la humanidad".

Palabras-clave: Educación Ciborgue. Currículo. Interpretación de la Humanidad.

\section{A VISÃO DE UMA EDUCAÇÃO CYBORG}

\section{RESUMO}

The Vision (King et al.) abre com um casal de subúrbio branco brigando enquanto trazem um prato com biscoitos quentes para seus novos vizinhos. O marido não vê o ponto de oferecer cookies para robôs, que provavelmente não precisam comer. Ao que a esposa responde: "Eles não são robôs. Eu fui online. Eles são outra coisa. Eles são synthe-somethings ". "Querida, eu amo você, mas são torradeiras. Torradeiras chiques e vermelhas. Eles não são como você e eu. Eles não comem biscoitos, sabe ?, "ele responde enquanto Vision abre a porta. Logo depois de Vision e sua esposa, Virginia, agradecer ao casal humano pelos biscoitos e oferecer-se para preparar um jantar uma noite, eles jogam os biscoitos na lata de lixo e conversam sobre o que consideram um ato sem sentido. É quando Vision fala com sua esposa Virginia: "Afirmar como verdade aquilo que não tem significado é a missão central da humanidade".

Palavras-chave: Educação Ciborgue. Currículo. Interpretação da Humanidade. 